narrow black line; six of the reddish lines are on the back and sides, one (interrupted) through the spiracles, and four on abdomen. Anal segments spotted with black, as also first, second and third segments. Mouth pinkish, legs pink, spotted with black ; spiracles dark colored.

It will be seen that the larva changes but little during growth. At the end of July they descend and bury themselves in the earth, changing in a few days to pupae, without forming any case. The pupa is brown, rather stout in form, and furnished at the tail with a small spine, which is generally bifid. It much resembles that of Amphidasys cognataria.

\title{
NEW SPECIES OF ACRIDINI FROM NEBRASKA.
}

BY G. M. DODGE, GLENCOE, DODGE CO., NEBRASKA.

\section{Pezotettix junius, n. s.}

Frontal costa slightly sulcate below the ocellus in the $\hat{\delta}$. Merely depressed at the ocellus in ${ }^{+}$.

Median carina of pronotum slight, cut by the last transverse incision behind the middle, the anterior part slightly arcuate. Lateral carinæ distinct only on the flat posterior lobe. Pronotum with sides slightly divergent; obtuse angled behind. Elytra cover about two-thirds of the abdomen. Posterior femora as long as abdomen. Last segment in $\hat{\sigma}$ squarely produced. $\hat{\delta}$ cerci broad, short, rounded at tip, slightly curved on upper edge. The lower edge bends upward, making an obtuse angle about the middle, from which point the cerci rapidly decrease in width.

Color of living insect--Varies with age from gray to green. Face and sides of thorax greenish gray. A broad black stripe from eye to last transverse incision of pronotum. Occiput brown. Pronotum brown with green stripe on each side. Antennae red, tips brown. Elytra brown, sometimes yellowish, with a few black dots along the disk. Hind femora light brown, usually with two oblique whitish bands on upper half. Three black spots on upper edge. Tip black. Inner side and lower sulcus light green. Abdomen greenish gray, with a row of large black spots on each side, sometimes forming an almost continuous longi- 
tudinal stripe. Abdomen sometimes mottled with black above, is greenish yellow below, with a narrow black line on the last segments below the fold. Sternum and anterior legs tinged with blue. Hind tibiae pale red with black spines. In the male the posterior segments of the abdomen are margined anteriorly with black.

Length of $q .90$ inch; elytra, .45 inch. Length of $\hat{\delta} .80$; elytra .40. Appears in June at Glencoe, Dodge Co., Nebraska.

\section{Pegotettix autumnalis, $n$. $s$.}

Frontal costa prominent above, suddenly widened and sulcate at the ocellus. Head unusually large, wider than thorax, occiput very long. Foveola of vertex shallow. Median carina of pronotum slight, cut once behind the middle. Sides of pronotum nearly parallel. Elytra short, oval, pointed. Abdomen rather long and slender, extending beyond the tips of hind femora in $q$. Male cerci nearly straight, broad at base, apical half slender and pointed. Tip of abdomen pointed entire.

Color of dried (not alcoholic) specimens-Face brown, white mottled with brown below clypeus. Cheeks yellow and brown. Antennae rufous. A black stripe from eye to last lobe of pronotum. A yellow spot below the black stripe. Remainder of pronotum brown, hind lobe lightest. Occiput brown margined with yellow. Elytra dark brown, unspotted. Abdomen dark above. Anterior legs yellow, marked with red above. Posterior femora yellow at base, then red on both sides and below, but heavily marked on upper side of exterior face with fuscous. Posterior tibiae blue.

Length of $q$ r.ro inch; elytra .25 inch. Length of $\hat{\delta} .85$ inch; elytra.203 inch. Glencoe, Nebraska, in September.

Pezotettix alba, n. s.

Form-Frontal costa sulcate, extending across clypeus in living specimens. Foveola of vertex hexagonal, shallow. Median carina of pronotum distinct, cut by last transverse impression back of the middle. Lateral carinæ rounded, nearly parallel. Elytra cross third abdominal segment in $q$. Wings minute. Legs long and slender. Male cerci long and slender. Terminal segment of abdomen entire acuminate. In the male the antennæ are longer than head and pronotum, and the posterior femora pass the abdomen one-fourth of their length.

Color of living insect- $\hat{\sigma}$, vertex, disk of pronotum and legs bright green. Face, abdomen and under side greenish white. Elytra a little 
darker. A white stripe from top of eye follows the lateral carinæ to the end of pronotum, and extends obliquely down the side to insertion of posterior femora. Below the white stripe, and running parallel with it, is a broad band of green followed by another white stripe.

Color of $q$ vertex, disk of pronotum and legs white, mottled with green. Rest like $\hat{\delta}$, but much whiter. Antennæ light brown.

Length of +.85 inch ; elytra .02 inch. Length of $\hat{\delta} .65$ inch.

Taken in August and September at Glencoe, Dodge Co., Nebraska.

\section{Caloptenus lurida, n. s.}

Size and form much like C. occidentalis Thos. Frontal costa with slight depression at ocellus, not sulcate. Foveola of vertex shallow, elongate, broadest in $q$. Median carina of pronotum slight, transverse impressions distinct. Lateral carinæ slightly divergent. Antennae longer than head and pronotum. Posterior femora as long as the abdomen. In the male the cerci are broad and flat, considerably curved and armed posteriorly with a rather long and sharp lateral tooth, giving them about the shape of the letter Y. Last ventral segment entire. In color this species, when living, is dark bluish gray. The pronotum and upper part of the head are sometimes lighter and tinged with red. Labrum bright red; antennae red at base, rest fuscous. Posterior femora light gray, with a longitudinal black stripe the entire length of the disk, and three black spots on the upper edge; the two posterior ones uniting with the black stripe and extending over upon the inner face. Tip black above, red below. Posterior tibiae blood red, with black spines.

In some specimens a light stripe on the side from base of elytra to posterior femora is apparent, but it is usually indistinct. Elytra cinereous darkest at base, with a central row of fuscous spots.

Length of 8.85 inch; of $q, 1.05$ inches.

Habitat, Dodge Co., Nebraska. Time of occurrence, September.

\section{Caloptemus regalis, $n$. $s$.}

ㅇ. Size medium. Frontal costa prominent; not sulcate, but depressed at the ocellus. Top of the head raised slightly above the pronotum. Antennae longer than head and thorax. Disk of pronotum gradually ascending toward median carina. Lateral carinae rounded. Pronotum depressed and cut near the middle by the last transverse incision. Hind border obtuse angled. 
Color of living insect-Face bluish white, mottled with brown. Cheeks blue, with an oblique darker patch. Eyes prominent, dark brown, hind margins dotted with black lines. Occiput with a triangular black spot, apex forward, bounded on each side by bright yellow. Sides of the thorax margined anteriorly with yellow. A black stripe behind the eye runs backward to the last transverse incision of pronotum. Below this stripe the sides are purplish blue, marked posteriorly with red. Disk of pronotum brown, margined with blue. Elytra gray, darkest at base. Disk white, containing a row of large black spots. Similar but smaller spots unequally distributed over the rest of the elytra. Apex dusky. Wings transparent, with white veins. Posterior femora externally red, with three oblique black bands. Inside and lower sulcus bright red. Upper edge bluish gray, with three broad black patches. Apex gray above, white outside, blue within, and marked with the usual black crescent-shaped patch. Hind tibiae bright blue, with a narrow white annulation near the knee. Tarsi blue above, white below. Anterior legs yellowish, mottled above with blue. Abdomen white, with the anterior part of each segment red, and a small black spot on each side. Beneath bluish white. Antennae light brown.

Length about one inch; length of elytra, .80 inch; length of hind femora, .55 inch. Habitat Glencoe, Nebraska. Appears in latter part of June.

\section{SUGARING FOR MOTHS.}

BY O. S. WESTCOTT, MAYWOOD, COOK CO., ILL.

The various preparations which have been recommended by different writers seem to be successful enough in attracting nocturnal Lepidoptera, while the poisons employed for quieting them seem to fail in one or more essential particulars. Cyanide of Potassium, whether alone or prepared with Plaster of Paris, does not act with sufficient readiness to prevent strong-bodied moths from fluttering so long as in a great measure to spoil the beauty of their vestiture, while the application of chloroform at night is attended with considerable inconvenience. I have found a plan like the following to work best in practice. 


\section{$2 \mathrm{BHL}$ Biodiversity Heritage Library}

Dodge, G M. 1876. "New species of Acridini from Nebraska." The Canadian entomologist 8, 9-12. https://doi.org/10.4039/Ent89-1.

View This Item Online: https://www.biodiversitylibrary.org/item/22083

DOI: https://doi.org/10.4039/Ent89-1

Permalink: $\underline{\text { https://www.biodiversitylibrary.org/partpdf/9549 }}$

\section{Holding Institution}

MBLWHOI Library

Sponsored by

MBLWHOI Library

\section{Copyright \& Reuse}

Copyright Status: NOT_IN_COPYRIGHT

This document was created from content at the Biodiversity Heritage Library, the world's largest open access digital library for biodiversity literature and archives. Visit BHL at https://www.biodiversitylibrary.org. 